\title{
Penguatan Literasi Digital melalui Model Pengembangan Kurikulum SMA Islam Berbasis Media Digital di Era 4.0
}

\author{
Bachtiar Adi Saputra ${ }^{1} \&$ Nurdiansyah $^{2}$ \\ Universitas Muhammadiyah Sidoarjo \\ 1bebebiologi@gmail.com \\ ²nurdyansyah@umsida.ac.id
}

\begin{abstract}
This paper aims to describe the strengthening of digital literacy through the development of digital media based Islamic high school curriculum in facing the challenges in 4.0 era. The method used in this study uses a qualitative descriptive approach with data collection techniques through direct observation and interviews. Based on the results of first observations at SMA Mubammadiyah 1 Park, the condition of the school has the potential that has not been maximized, namely the use of digital media in learning. Strengthening digital literacy is done through a model of curriculum development based on digital media in designing objectives, materials, strategies and evaluating learning. The digital literacy component that is the focus of research includes skills in information literacy and media literacy; digital scholarship skills, media literacy, learning skills, ICT literacy through guided assignments using digital media; and communication and collaboration skills through the active participation of students by using their digital media to collaborate and communicate in learning. This research is expected to make a positive contribution in the model of curriculum development in Islamic bigh schools that is in line with the times, through strengthening digital literacy to face challenges in 4.0 era.
\end{abstract}

Keywords: Digital literacy, Curriculum development, Islamic high school, 4.0 Era

\begin{abstract}
Abstrak: Tulisan ini bertujuan untuk mendeskripsikan penguatan literasi digital melalui model pengembangan kurikulum SMA Islam berbasis media digital dalam menghadapi tantangan di era 4.0. Metode yang digunakan dalam penelitian ini menggunakan pendekatan deskriptif kualitatif dengan teknik pengumpulan data melalui observasi langsung serta wawancara. Berdasarkan hasil observasi awal di SMA Muhammadiyah 1 Taman, kondisi sekolah memiliki potensi yang belum termaksimalkan yaitu pemanfaatan media digital dalam pembelajaran. Penguatan literasi digital dilakukan melalui model pengembangan kurikulum yang berbasis media digital dalam merancang tujuan, materi, strategi maupun evaluasi pembelajarannya. Komponen literasi digital yang menjadi fokus penelitian meliputi keterampilan dalam information literacy and media literacy; keterampilan digital scholarship, media literacy, learning skills, ICT literacy melalui penugasan terbimbing menggunakan media digital; serta keterampilan communication and collaboration melalui partisipasi aktif peserta didik dengan menggunakan media digitalnya untuk berkolaborasi dan
\end{abstract}

Islamika : Jurnal Keislaman dan Ilmu Pendidikan

Volume 2, Nomor 1, Januari 2020; 36-45

https:// ejournal.stitpn.ac.id/index.php/islamika 
berkomunikasi dalam pembelajaran. Penelitian ini diharapkan bisa memberikan kontribusi positif dalam model pengembangan kurikulum di SMA Islam yang sesuai dengan perkembangan zaman melalui penguatan literasi digital untuk menghadapi tantangan di era 4.0.

Kata Kunci : Literasi Digital, Pengembangan Kurikulum, SMA Islam, Era 4.0

\section{PENDAHULUAN}

Perkembangan zaman sudah mencapai era revolusi keempat (4.0) atau bisa disebut dengan era revolusi digital. Pada era ini, semua informasi dapat diperoleh secara up to date tanpa batasan ruang maupun waktu melalui komunikasi internet. Perkembangan media informasi dimulai sejak tahun 1607 dengan beredarnya surat kabar atau koran, berlanjut pada penggunaan telegram, telepon, radio, televisi, jam digital, mp3, komputer, laptop, hingga sekarang semakin berkembang pesat dengan adanya berbagai macam smartphone.

Perkembangan tersebut telah menciptakan sebuah wahana baru bernama cyberspace yang telah mengalihkan berbagai aktivitas manusia di dunia nyata ke dalam berbagai bentuk artifisialnya dalam dunia maya yaitu internet. ${ }^{2}$ Berdasarkan data yang dirangkum oleh we are social and hootsuites ${ }^{3}$ sebagian besar masyarakat Indonesia menghabiskan waktu hampir 8 jam lebih dalam mengakses ienternet setiap harinya (lihat tabel 1).

\section{Tabel 1. Lama Waktu yang Dihabiskan untuk Mengakses Media}

\begin{tabular}{|c|l|c|}
\hline No & \multicolumn{1}{|c|}{ Aktivitas Media } & Lama Waktu per hari \\
\hline 1 & Mengakses Internet & 8 jam, 36 menit \\
\hline 2 & Menggunakan media social & 3 jam, 26 menit \\
\hline 3 & Melihat televisi & 2 jam, 52 menit \\
\hline 4 & Mendengarkan musik & 1 jam, 22 menit \\
\hline
\end{tabular}

Indonesia merupakan salah satu negara dengan pertumbuhan pengguna internet yang signifikan, yaitu sekitar $10 \%$ per tahun. Hal tersebut terlihat dari laporan hasil survei yang dilakukan oleh APJII pada bulan maret sampai april 2019

${ }^{1}$ Kemendikbud. Realitas Virtual Era Revolusi Industri 4.0. (Jakarta: Direktorat Pembinaan Pendidikan Keaksaraan dan Kesetaraan, Kementerian Pendidikan dan Kebudayaan, 2018).

2 Piliang, Yasraf Amir. "Masyarakat Informasi dan Digital: Teknologi Informasi dan Perubahan Sosial." Jurnal Sosioteknologi Edisi 27 Tahun 11, (2012), 145.

${ }^{3}$ wearesocial, and hootsuite. Digital 2019. New York: We are social and hootsuite, 2019. 
didapatkan hasil kenaikan pengguna internet dari 54,68 \% di tahun 2017 menjadi $64,8 \%$ di tahun 2018. Hasil pesentase tersebut didapat dari perhitungan pengguna internet berjumlah 143,26 juta jiwa per 262 juta populasi penduduk Indonesia di tahun 2017 dan 171,17 juta jiwa per 264,16 juta populasi penduduk Indonesia di tahun 2018 (lihat grafik 1).

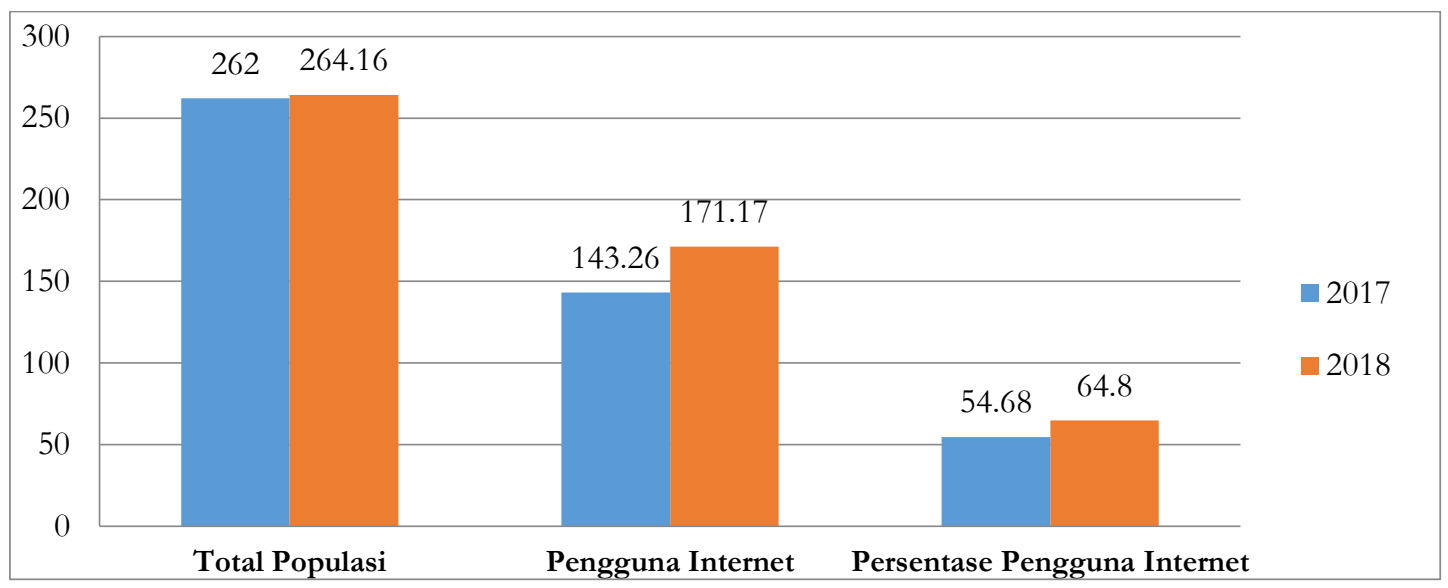

Grafik 1. Penggunaan Internet di Indonesia Periode Tahun 2017-2018

(Hasil Survey APJII 2019) ${ }^{4}$

Perkembangan era digital yang sangat pesat tersebutperlu diimbangi dengan penyiapan sumber daya manusia (SDM) yang kreatif, inovatif, serta kompetitif.Peningkatan kualitas SDM yang baik akanmenjadi kunci dalam menghadapi perkembangan era digital melalui proses pendidikan yang mampumengoptimalkan penggunaan kemajuan dunia digital sebagai alat bantu pendidikan. Sehinggabidang pendidikan diharapkan mampu menghasilkan output yang dapat mengikuti atau mengubah zaman menjadi lebih baik. ${ }^{5}$

Merujuk pada penyiapan SDM yang baik, maka dunia pendidikan perlu merumuskan pengembangan kurikulum yang sesuai dengan perkembangan era digital.Sesuai dengan prinsip pengembangan kurikulum yaitu relevansi antara kualitas lulusan yang dihasilkan dengan tuntutan perubahan zaman yang ada di masyarakat.Seperti yang dijelaskan oleh Sukmadinata ${ }^{6}$ bahwa relevansi kurikulum

${ }^{4}$ APJII (Asosiasi Penyelenggara Jasa Internet). Laporan Survei Penetrasi \& Profil Perilaku Pengguna Internet Indonesia 2018. (Jakarta: Asosiasi Penyelenggara Jasa Internet, 2018).

${ }^{5}$ Lase, Delipiter. "Pendidikan di Era Revolusi Industri 4.0." dalam www.researchgate.net/publication/2019 diakses tanggal 15 Desember 2019

${ }^{6}$ Sukmadinata, Nana Syaodih. Pengembangan Kurikulum: Teori dan praktik. Bandung: Remaja Rosdakarya, 2005. 
secara eksternal yaitu tujuan pembelajaran, materi dan kegiatan pembelajaran yang tertuang dalam kurikulum sebaiknya sesuai dengan perkembangan kehidupan yang ada di masyarakat. Sedangkan menurut Subandijah ${ }^{7}$, pendidikan harus relevan dengan perkembangan ilmu pengetahuan dan teknologi yang semakin maju setiap tahunnya.Pendidikan harus mampu menyiapkan peserta didik sebagai produsen ilmu pengetahuan dan teknologi bukan hanya sebagai konsumen iptek yang terus menerus berkembang.

Kemajuan iptek terutama kecanggihan teknologi informasi yang senantiasa berkembang perlu diimbangi dengan pembelajaran yang mengedepankan penguasaan teknologi digital dalam proses pembelajarannya atau bisa disebut pembelajaran digital. $^{8}$ Tuntutan tersebut menjadi dasar penulisan ini sehingga penulis menitikberatkan tujuan penelitian pada penguatan literasi digital melalui model pengembangan kurikulum SMA Islam berbasis media digital dalam menghadapi tantangan di era 4.0 .

\section{METODE}

Metode penelitian yang digunakan adalah penelitian deskriptif kualitatif untuk mendeskripsikan penguatan literasi digital SMA Islam di era 4.0 dan menganalisa efektifitas model pengembangan kurikulum di SMA Islam berbasis media digital. Pengumpulan data dilakukan dengan observasi langsung pada kegiatan pembelajaran yang menggunakan media digital, sedangkan wawancara dilakukan dengan guru pengampu mata pelajaran ISMUBA serta kepada peserta didik.

\section{HASIL DAN DISKUSI}

Penelitian ini dilakukan di SMA Muhammadiyah 1 Taman sebagai salah satu SMA Islam yang sedang berkembang di kabupaten Sidoarjo. Kurikulum pendidikan yang digunakan di SMA Muhammadiyah 1 Taman terdapat pembelajaran khas Muhammadiyah yaitu ISMUBA (Al Islam, Kemuhammadiyahan dan Bahasa Arab). Berdasarkan hasil observasi dan wawancara pada peserta didik maupun guru ISMUBA terdapat beberapa permasalahan dasar yaitu kurangnya ketertarikan peserta

${ }^{7}$ Subandijah. Pengembangan dan Inovasi Kurikulum. (Jakarta: Raja Grafindo Persada, 1993).

8 Anggraini, S. "Budaya Literasi Dalam Komunikasi." W ACANA, XV, Vol. 3 (2016), 181-279. 
didik dalam mempelajari kurikulum pendidikan Islam karena sebagian besar peserta didik lebih banyak asyik dengan dunia digitalnya.

Sesuai dengan instruksi dari kepala sekolah, digunakanlah inovasi pembelajaran yang dilakukan oleh guru-guru ISMUBA dengan membawa peserta didik mengamati lingkungan sekitar maupun membawakan materi melalui powerpoint atau video yang menjadi pendamping pembelajaran berupa modul yang sudah dibagikan kepada peserta didik. Akan tetapi, dalam implementasinya masih terdapat peserta didik yang acuh pada pembelajaran, karena bagi peserta didik dunia digital mereka masih lebih asyik.

Oleh karena itu diperlukan pengembangan kurikulum yang disesuaikan dengan perkembangan dunia digital, yaitu dengan memanfaatkan media pembelajaranberbasis digital untuk melatihpeserta didik dalam menguasai keterampilan literasi digital. Sesuai dengan penjelasan dari tim gerakan literasi nasional yang disusun oleh Kemendikbud ${ }^{9}$ bahwa literasi digital merupakan wawasan serta keterampilan dalam menggunakan media digital baik berupa alat maupun jaringan komunikasi melalui pemanfaatan hingga pembuatan informasi digital untuk melatih interaksi sosial dalam keseharian yang bijak dan taat aturan.

Hal tersebut sejalan dengan kebutuhan era 4.0 dimana perkembangan dunia yang semakin canggih memerlukan sumber daya manusia yang melek atau faham dalam memanfaatkan informasi secara bijak untuk memenuhi kebutuhannya. Sesuai dengan komponen literasi digital berupa information literacy yaitu keterampilan dalam menggunakan informasi secara bijak baik dalam proses pencarian, pemakaian hingga pemahaman informasi yang didapatkan untuk kebutuhan sendiri maupun disebarluaskan. ${ }^{10}$ Didukung juga oleh penjelasan Sukono dalam Seminar Nasional IKA UNY ${ }^{11}$ perlu kemampuan dalam memanfaatkan teknologi digital dalam proses pembelajaran, penyelesaian berbagai tugas, dan peningkatan kompetensi guru maupun peserta didik utnuk menghadapiperkembangan zaman yang sangat pesat.

${ }^{9}$ Kemendikbud, GLN. Materi Pendukung Literasi Digital. (Jakarta: Kemendikbud, 2017).

${ }^{10}$ Hasugian, J. "Urgensi Literasi Informasi dalam Kurikulum Berbasis Kompetensi di Perguruan Tinggi. ." Pustaka: Jurnal Studi Perpustakaan Dan Informasi, Vol. 4, No. 2 (2008), 34-44.

${ }^{11}$ Sukono. "Memanfaatkan Kemajuan Teknologi untuk Meningkatkan Kompetensi Guru." Prosiding "Profesionalisme Guru Abad XXI", 2018. 
Berdasarkan gambaran dari JISC ${ }^{12}$ selain information literacy, penguatan literasi digital dalam menghadapi era 4.0 juga meliputi digital scholarship, media literacy, learning skills, ICT literacy, career andidenty management serta communication and collaborationseperti yang diilustrasikan dalam gambar 2 .

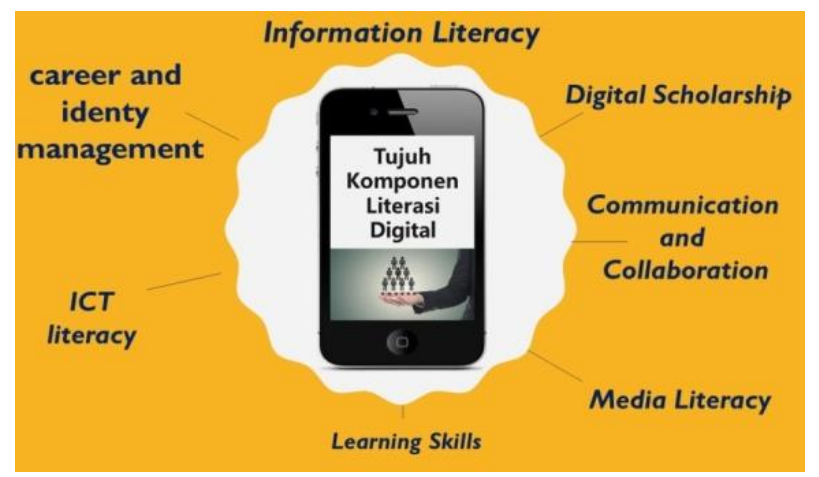

Gambar 2. Tujuh Komponen Literasi Digital

Komponen literasi digital berupa digital scholarship merupakan kemampuan individu dalam memanfaatkan informasi ataupun peralatan digital untuk kebutuhan pendidikannya seperti penelusuran materi dalam proses penyelesaian tugas maupun pustaka untuk keperluan penelitian lanjutan. ${ }^{13}$ Komponen literasi digital selanjutnya adalah learning skills yang berarti keterampilan individu dalam memanfaatkan teknologi sebagai proses pembelajaran mandiri baik melalui pembelajaran di dalam maupun di luar kelas resmi. ${ }^{14}$ Setelah keterampilan pembelajaran, literasi digital juga meliputi kemampuan dalam literasi media atau media literacy yang berarti kecakapan seseorang dalam memilih, memilah, maupun mengolah media digital yang ada untuk digunakan secara bijak dalm proses pemenuhan kebutuhannya. ${ }^{15}$

Selain itu juga terdapat komponen ICT literacy yang merupakan keterampilan individu dalam memanfaatkan media digital berbasis TIK dalam kesehariannya

12 JISC. Developing digital literacies. JISC, 2017.

${ }^{13}$ Stefani, S. N. B. "Literasi Digital dan Pembukaan Diri: Studi Korelasi Penggunaan Media Sosial Pada Pelajar Remaja di Kota Medan." Sosioglobal, Jurnal Pemikiran Dan Penelitian Sosiologi, Vol. 2, No. 1 (2017), 10-31.

${ }^{14}$ Setyaningsih, Rila, Abdullah, Edy Prihantono, and Hustinawati. "Model Penguatan Literasi Digital Melalui Pemanfaatan E-Learning." Jurnal ASPIKOM Vol 3, No. 6 (2019), 1200-1214.

${ }^{15}$ Rianto, P. " Media Baru, Visi Khalayak Aktif dan Urgensi Literasi Media." Jurnal Komunikasi Ikatan Sarjana Komunikasi Indonesia, Vol. 1, No. 2 (2016), 90-96. 
terutama yang terkait dengan proses pembelajaran. ${ }^{16}$ Komponen lainnya adalah career and identy management yang berarti kemampuan mengatur identitas diri seperti pembuatan username, password, icon yang akan menjadi acuan orang lain mengenali profil diri kita. ${ }^{17}$ Serta kemampuan paling kompleks dari literasi digital adalah kemampuan dalam hal berkolaborasi dan berkomunikasi, dalam kehidupan proses bersosialisasi kolaborasi dan komunikasi merupakan kunci untuk bisa menyesuaikan diri dalam lingkungan sekitarnya. Oleh karena itu, adanya media digital harus bisa membuat kehidupan sosial kita menjadi lebih baik melalui penguasaan keterampilan berkolaborasi dan berkomunikasi dengan sesama.

Berdasarkan ringkasan tentang komponen literasi digital, berikut ulasan mengenai penguatan literasi digital melalui model pengembangan kurikulum berbasis media digital di SMA Muhammadiyah 1 Taman (lihat tabel 2).

Tabel 2. Penguatan Literasi Digital melalui Model Pengembangan Kurikulum Berbasis

Media Digital

\begin{tabular}{|c|c|c|}
\hline No & $\begin{array}{c}\text { Komponen Literasi } \\
\text { Digital }\end{array}$ & $\begin{array}{l}\text { Komponen Kurikulum Berbasis Media } \\
\text { Digital }\end{array}$ \\
\hline \multirow{4}{*}{1} & \multirow{4}{*}{$\begin{array}{l}\text { Information literacy } \\
\text { and } \\
\text { Media literacy }\end{array}$} & $\begin{array}{l}\text { 1. Tujuan }=\text { Membina peserta didik yang } \\
\text { menguasai keterampilan literasi informasi } \\
\text { dan media berlandaskan keimanan dan } \\
\text { ketaqwaan }\end{array}$ \\
\hline & & $\begin{array}{l}\text { 2. Materi }=\text { Menyiapkan beberapa link } \\
\text { materi di media digital (media sosial, } \\
\text { website) yang berhubungan dengan } \\
\text { informasi tentang menjadi khalifah fil ard }\end{array}$ \\
\hline & & $\begin{array}{l}\text { 3. Strategi }=\text { Menggunakan peralatan digital } \\
\text { peserta didik untuk mengakses materi } \\
\text { yang telah disiapkan }\end{array}$ \\
\hline & & $\begin{array}{l}\text { 4. Evaluasi }=\text { Membuat post test tentang } \\
\text { materi khalifah fil ard melalui link di google } \\
\text { form }\end{array}$ \\
\hline
\end{tabular}

${ }^{16}$ Budhirianto, S. "Model Pember dayaan Relawan TIK Dalam Meningkatkan E-Literasi Masyarakat di Kota Sukabumi. ." Jurnal Penelitian Pos Dan Informatika, Vol. 6, No.1 (2016), 19-36.

${ }^{17}$ Damayanti, T., M. Y. Setiani, and B. Oetojo. "E-Learning pada pendidikan jarak jauh: konsep yang mengubah metode pembelajaran di perguruan tinggi di Indonesia. ." Jurnal Pendidikan Terbuka Dan Jarak Jauh, Vol. 8, No. 2 (2007), 99-113. 


\begin{tabular}{|c|c|c|}
\hline \multirow{4}{*}{2} & \multirow{4}{*}{$\begin{array}{l}\text { Digital scholarship, } \\
\text { Learning skills } \\
\text { and } \\
\text { ICT literacy }\end{array}$} & $\begin{array}{l}\text { 1. Tujuan }=\text { Membiasakan peserta didik } \\
\text { untuk memanfaatkan peralatan maupun } \\
\text { jaringan digital sebagai proses } \\
\text { keterampilan belajar baik untuk } \\
\text { mengerjakan tugas maupun penelitian } \\
\text { tentang Al Islam }\end{array}$ \\
\hline & & $\begin{array}{l}\text { 2. } \text { Materi }=\text { Menyiapkan materi berupa } \\
\text { biografi tokoh-tokoh Islam di media } \\
\text { digital }\end{array}$ \\
\hline & & $\begin{array}{l}\text { 3. Strategi }=\text { Melatih peserta didik } \\
\text { menggunakan peralatan digitalnya untuk } \\
\text { kebutuhan pembelajaran, penyelesaian } \\
\text { tugas Al Islam maupun penelitian lanjutan }\end{array}$ \\
\hline & & $\begin{array}{l}\text { 4. Evaluasi }=\text { Menggunakan media digital } \\
\text { berupa email ataupun google form dalam } \\
\text { pengumpulan tugas ISMUBA terbimbing } \\
\text { maupun tes evaluasi yang memanfaatkan } \\
\text { computer based test }\end{array}$ \\
\hline \multirow{4}{*}{3} & \multirow{4}{*}{$\begin{array}{c}\text { Communication and } \\
\text { collaboration }\end{array}$} & $\begin{array}{l}\text { 1. } \text { Tujuan }=\text { Melatih peserta didik untuk } \\
\text { berpartisipasi secara aktif dengan } \\
\text { menggunakan media digitalnya untuk } \\
\text { berkolaborasi dan berkomunikasi dalam } \\
\text { pembelajaran }\end{array}$ \\
\hline & & $\begin{array}{l}\text { 2. Materi }=\text { Menyiapkan materi tentang } \\
\text { amalan-amalan sebagai khalifah yang baik } \\
\text { dari berbagai platform media digital }\end{array}$ \\
\hline & & $\begin{array}{l}\text { 3. Strategi }=\text { Melatih peserta didik untuk } \\
\text { berdiskusi dan menyampaikan hasil } \\
\text { diskusinya berupa teks, gambar maupun } \\
\text { video yang bisa diupload di media digital }\end{array}$ \\
\hline & & 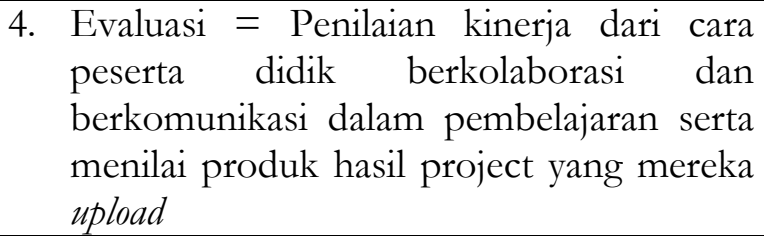 \\
\hline
\end{tabular}

Pemanfaatan media digital sebagai model pengembangan kurikulum di SMA Islam seperti yang dilakukan di SMA Muhammadiyah 1 Taman mengenai materi khalifah fil ard merupakan upaya untuk menguatkan keterampilan literasi digital melalui pemanfaatan media yang mereka biasa gunakan dalam kehidupan sehariharinya. Sesuai dengan pendapat dari Umam $\mathrm{dkk}^{18}$ bahwa pembelajaran yang melibatkan media digital lebih efektif bagi pelajar millennial karena pembelajaran

${ }_{18}$ Umam, Kaiful, and Zaini. "Penerapan Media Digital Dalam Pembelajaran Apresiasi Batik Kelas X SMA Negeri 1 Blega." Jurnal Pendidikan Seni Rupa, Vol. 1, No. 1 (2013), 100-105. 
menjadi lebih menarik dan interaktif dengan adanya berbagai bentuk gambaran yang bisa disajikan oleh media digital.

Hal tersebut juga sejalan dengan gagasan dari Azra ${ }^{19}$ bahwa kurikulum pendidikan Islam harus berkembang yaitu memberikan penekanan pada pemanfaatan ilmu pengetahuan dan teknologi dengan tetap berlandaskan pada nilai-nilai agama yang kuat. Hingga akhirnya pendidikan Islam bisa berfungsi untuk menyiapkan dan membina SDM yang berkualitas yaitu generasi muslim yang menguasai iptek dengan berpegang teguh pada keimanan yang dapat bermanfaat bagi masyarakat.

\section{KESIMPULAN}

Dalam penulisan ini dapat disimpulkan bahwa penguatan literasi digital diperlukan guna menghadapi tantangan di era 4.0 yang dikenal dengan era digital karena berkembang pesatnya teknologi informasi yang saat ini sudah banyak menggunakan media digital. Penguatan literasi digital dapat dilakukan melalui model pengembangan kurikulum pendidikan SMA Islam yang memanfaatkan media digital dalam tujuan, materi, strategi maupun evaluasi pembelajarannya untuk melatihkan keterampilan information literacy, media literacy, digital scholarship, media literacy, learning skills, ICT literacy serta communication and collaboration.

\section{DAFTAR PUSTAKA}

APJII (Asosiasi Penyelenggara Jasa Internet). Laporan Survei Penetrasi \& Profil Perilaku Pengguna Internet Indonesia 2018. (Jakarta: Asosiasi Penyelenggara Jasa Internet, 2018).

Anggraini, S. "Budaya Literasi Dalam Komunikasi." WACANA, XV(3), 2016: 181279.

Azra, Azyumardi. Pendidikan Islam: Tradisi dan Modernisasi di Tengah Tantangan Milenium III. Jakarta: Kencana kerja sama dengan UIN Jakarta Press., 2012.

Budhirianto, S. "Model Pember dayaan Relawan TIK Dalam Meningkatkan ELiterasi Masyarakat di Kota Sukabumi. ." Jurnal Penelitian Pos Dan Informatika, 6(1), 2016: 19-36.

\footnotetext{
19 Azra, Azyumardi. Pendidikan Islam: Tradisi dan Modernisasi di Tengah Tantangan Milenium III. (Jakarta:
} Kencana kerja sama dengan UIN Jakarta Press, 2012). 
Damayanti, T., M. Y. Setiani, and B. Oetojo. "E-Learning pada pendidikan jarak jauh: konsep yang mengubah metode pembelajaran di perguruan tinggi di Indonesia. ." Jurnal Pendidikan Terbuka Dan Jarak Jauh, 8(2), 2007: 99-113.

Hasugian, J. "Urgensi Literasi Informasi dalam Kurikulum Berbasis Kompetensi di Perguruan Tinggi. ." Pustaka: Jurnal Studi Perpustakaan Dan Informasi, 4(2), 2008: 34-44.

JISC. Developing digital literacies. JISC, 2017.

Kemendikbud. Realitas Virtual Era Revolusi Industri 4.0. Jakarta: Direktorat Pembinaan Pendidikan Keaksaraan dan Kesetaraan, Kementerian Pendidikan dan Kebudayaan, 2018.

Kemendikbud, GLN. Materi Pendukung Literasi Digital. Jakarta: Kemendikbud, 2017. Lase, Delipiter. "Pendidikan di Era Revolusi Industri 4.0." www.researchgate.net/publication, 2019.

Piliang, Yasraf Amir. "Masyarakat Informasi dan Digital: Teknologi Informasi dan Perubahan Sosial." Jurnal Sosioteknologi Edisi 27 Tabun 11, 2012: 145.

Rianto, P. " Media Baru, Visi Khalayak Aktif dan Urgensi Literasi Media." Jurnal Komunikasi Ikatan Sarjana Komunikasi Indonesia, 1(2), 2016: 90-96.

Setyaningsih, Rila, Abdullah, Edy Prihantono, and Hustinawati. "Model Penguatan Literasi Digital Melalui Pemanfaatan E-Learning." Jurnal ASPIKOM Vol 3 (6) , 2019: 1200-1214.

Stefani, S. N. B. "Literasi Digital dan Pembukaan Diri: Studi Korelasi Penggunaan Media Sosial Pada Pelajar Remaja di Kota Medan. ." Sosioglobal, Jurnal Pemikiran Dan Penelitian Sosiologi, 2(1), 2017: 10-31.

Subandijah. Pengembangan dan Inovasi Kurikulum. Jakarta: Raja Grafindo Persada, 1993. Sukmadinata, Nana Syaodih. Pengembangan Kurikulum: Teori dan praktik. Bandung: Remaja Rosdakarya, 2005.

Sukono. "Memanfaatkan Kemajuan Teknologi untuk Meningkatkan Kompetensi Guru." Prosiding "Profesionalisme Guru Abad XXI”, 2018.

Umam, Kaiful, and Zaini. "Penerapan Media Digital Dalam Pembelajaran Apresiasi Batik Kelas X SMA Negeri 1 Blega." Jurnal Pendidikan Seni Rupa, 1(1), 2013: 100-105.

wearesocial, and hootsuite. Digital 2019. New York: We are social and hootsuite, 2019. 